\title{
Horticulturists Must Take Charge of Their Own Destiny Presidential Address ${ }^{1}$
}

\author{
J. Benton Storey ${ }^{2}$ \\ ASHS President, 1993-94
}

The future of horticulture is what we make it. We must stand for something. We cannot stand still and watch the world go by. We have to be active participants in it.

\section{Publications}

Our publications are perhaps the most important way in which we participate in the world community. They provide an essential vehicle for presenting new knowledge to a diverse, horticulturally interested audience of both authors and readers. In its 90+ years of existence, ASHS has built an enviable reputation for quality publications. Your continued support of the publications by making yourself available as a peer reviewer is essential to the continued premier place the publications hold, not only in academia, but in the extension offices and the horticultural industries.

Dan Cantliffe told the story of visiting a grower in southern Florida. He was invited to make the usual ride into the fields to see if his latest recommendation was working. When he got in the pickup (which doubled as the grower's office), he sat on something - that something was a copy of HortTechnology. This publication is finding its way into the mainstream. It is being quoted by editors of horticultural trade journals. HortTechnology is making a difference, just as its sponsor-the Extension Division—-promised it would. We must be vigilant to make sure that it continues to be directly applicable to growers and extension agents. Extension is our front line, and we need to support them in their mission in every way possible.

We can reduce the submission-to-publication time from our current 10 to 12 months to 4 to 7 months if we all work at it. If the publications are not coming fast enough for you, call the Publications Dept. and tell them that you want to be a reviewer. Do something about it. Take charge of your own destiny.

\section{A voice is needed in Washington, D.C.}

We have quit standing idly by and letting Congress do what it wants with our lives. We have added an "h" to our 501(c)(3) IRS classi-

${ }^{1}$ Presented at the 91st annual meeting of the American Society for Horticultural Science, Corvallis, Ore., 10 Aug. 1994.

Viewpoints are published in HortScience to provide members of the American Society for Horticultura Science an opportunity to share their experiences and comments on matters of concern to horticulturists. These are not statements of official Society policy, nor do they necessarily reflect the views of a majority of the Society's members.

${ }^{2}$ Dept. of Horticultural Sciences, Texas A\&MUniv., College Station, TX 77843.

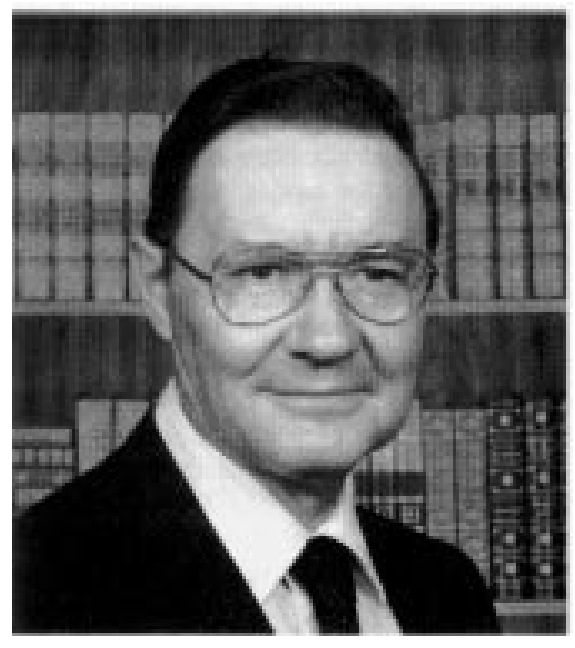

fication, which makes it possible for us to legally use up to $10 \%$ of our budget for lobbying if we choose to do so. We will never come close to that amount, but it is good to know that we can follow the recommendation of the National Issues Committee so that we can use our Washington, D.C., headquarters location to our advantage. Our Executive Director has free and easy access to the staffs of the important committees.

E.E. Finney, Jr., acting administrator, Agricultural Research Service (ARS), announced on 9 Feb. 1994 that 19 ARS locations were being left out of President Clinton's budget for the next fiscal year beginning on 1 Oct. ARS locations on the list that conduct horticultural research are the blueberry and cranberry program at Chatsworth, N.J.; the pecan breeding program at Brownwood, Texas; the Subtropical Horticultural Research Laboratory at Miami; natural resources and crop production at Brawley, Calif.; potato research at East Grande Forks, Minn.; the seedling tree and dutch elm disease research at Delaware, Ohio; and the citrus and subtropical research at Pasadena, Calif.

We became directly involved through our National Issues Committee. While in Washington on other ASHS business, I made two trips to Capitol Hill to provide information to the staff of the House Appropriations Subcommittee on Agriculture, which is under the leadership of Congressman Durbin, and to the staff of the House Agriculture Committee, which is under the leadership of Congressman Kika de la Garza. The North American Blueberry Council and the National Pecan Growers Council became involved, as well as many others throughout the country. The other locations seemed to be moving ahead on their own, so we concentrated on Chatsworth and Brownwood. The April ASHS Newsletter featured the desperate need to save the natural heritage that we have in Vaccinium and Carya. Members of Congress and senators contacted me by letter, phone, and fax for information.

As horticulturists, we have a responsibility to preserve, develop, and cultivate the inheritance that has been given to us. We have responded by establishing repositories and breeding programs designed to assemble the genetic diversity within genera that currently have, or may have, commercial value in the future. The first ASHS committee that I ever served on was the Clonal Repository Committee. I remember a meeting of that committee at the Univ. of Illinois in 1965, when our most outspoken committee member, Freeman S. Howlett, made an impassioned speech about the tragic loss of Malus germplasm. He said that the young apple breeders of that day were selecting what they wanted from their breeding material and throwing away the rest. He went on to say that we had to have clonal repositories to support the breeding effort if we ever expected to receive full benefits from breeding. I was very impressed by Howlett's statement, and still am, for his words of wisdom still hold today.

The Vaccinium and Carya breeding programs are near the top of a long list of costeffective and far-reaching research projects conducted by the ARS. It is appropriate that ARS take the leadership in an effort that affects the common heritage of every citizen on the North American continent. We have limited numbers of indigenous fruit-producing, commercial, horticultural genera in this part of the world. Of these, blueberries, cranberries, and pecans are in danger of losing their fundamental research base. The ARS's Carya program is the only pecan breeding program in the world. It takes 25 years from a controlled cross to final introduction of a new cultivar. The breeding pipeline is full, and new selections are subject to being made each year, but if the program is ended, it will never start again, and the 25 years will be lost and no one will ever be patient enough to start another one.

It is ironic that breeding programs aimed at reducing pesticide usage through incorporating host-plant resistance into new cultivar releases are selected for destruction so that funds can be redirected to reducing the use of pesticides, one of the stated new ARS research priorities. Now come on! Isn't it obvious that spraying 15 times for pecan scab is more dangerous to the environment than breeding new cultivars that incorporate disease resistance and require no pesticides? Stated plainly and simply, there is no better way to reduce pesticides than to develop disease-and insectresistant cultivars.

Some have predicted that, by the year 2000, the U.S. Dept. of Agriculture (USDA) will be 
reduced to a regulatory agency. We cannot stand by and let that happen. A far better course would be to direct their research efforts to objectives that benefit a large number of people in a large number of states. For example, breeding for insect and disease resistance can best be done by a federal agency rather than by states, where more narrow objectives would be selected. If the ARS chooses to work on cultural research that could just as easily be conducted at the state level rather than at the fundamental breeding level-the USDA may well be in trouble and, indeed, could be reduced to a regulatory role.

We met in early May with George Teetes, president of the Entomological Society of America, and representatives of six other societies. The Environmental Protection Agency (EPA) representative made it clear that prescription pesticides were the only way that many new labels could be issued for horticultural crops, which are all minor crops. Registration for regular use will be too expensive. We are making sure that the EPA knows about Certified Professional Horticulturists and Board Certified Entomologists. These certifications will enable many of our BS graduates to take charge of their own destiny and provide a service that will grow in demand.

ARS officials stated that they conducted careful reviews before deciding to close the 19 locations. How could these have been thorough reviews when none of the Crop Advisory Committees (CAC) were consulted. Why do we have CACs when they are not consulted on the very life or death of the program they are supposed to advise? ASHS needs to work hard, as we can help ARS prioritize research needs before the order to cut comes down from the Secretary of Agriculture. Programs affecting large numbers of states should have priority over research of local significance. The state experiment stations should pick up provincial needs.

John Clark, Univ. of Arkansas, writes that the USDA effort is the basis for the expansion of the blueberry industry. The relocation of the blueberry breeder position to New Jersey from its previous location in Beltsville, Md., was to be a long-term move to stabilize the blueberry breeding effort. This effort will be negated if the ARS closing is carried out. The ARS closing is still central to the total U.S. industry, and this effort is based at Chatsworth, N.J. Therefore, the closure of the Chatsworth location is unacceptable under any circumstances.

ARS officials have stated that the matter is in the hands of Congress. Congress is not supposed to understand scientific principles and logic, but the USDA, with all of its expertise, is supposed to come to conclusions that can be defended by scientific logic.

\section{National Research Initiative}

I attended the Board on Agriculture meeting at the Univ. of California, Irvine, in Fall 1993 and learned a great deal. I had never been to a meeting of that kind, which was heavy with upper administration from USDA and academia, plus other science society presi- dents. I tried not to do anything that would embarrass ASHS. We came to the small group meeting, where we discussed the USDA competitive grant program, otherwise known as the National Research Initiative (NRI). Some seemed pleased that this was a great program because such a small percentage of the grant proposals were accepted. I asked the question that I thought appropriate, which was, "Has anyone ever estimated the millions of tax dollars that had been spent each year for preparation of unsuccessful grant proposals?" That got everyone's attention. I was told that a person who had not been successful was a better scientist for having gone through the process. Somehow, instead of feeling better off, I have always felt let down and dejected when my proposal is judged not to measure up. I have wondered how much more research I could have been done if I had been in the laboratory or orchard for the 2 months that the proposal took out of my life.

When I started to work in a land-grant university, I never had a problem with a shortage of research funds. Now it is a different matter. What has happened to the research funds? There are many answers, but the Cooperative State Research Service, which is the source of our Hatch funds, has been reduced to a shell. No increase in Hatch funds for years has allowed inflation to take its toll. Part of the funds were set aside for NRI so that we could be sure that the research would be "good science." The original arrangement was that $50 \%$ would go to applied research and 50\% to basic research. The Hatch funds had predominately gone to applied research, which fit horticulture researchers well because horticulture is an application of biochemistry, physiology, genetics, pathology, and other sciences.

With this 50/50 arrangement in mind, what is the problem? Are all of the proposals that are designed to help a grower become solvent and pay off bank loans suddenly "bad science"? We surveyed the 1993 NRI awards in the categories "Plant Response to the Environment," "Plant Genetics and Molecular Biology," "Plant Growth and Development," "Nitrogen Fixation and Metabolism," "Plant Pathology and Weed Science, Entomology, and Nematology," "Alcohol Fuels," and "Plant Genomes."We found that $80 \%$ of the successful proposals were basic science. Only $20 \%$ could be considered of use to contemporary practitioners who have to meet a payroll each week. The money breakdown was $\$ 34.4$ million $(80.6 \%)$ awarded for basic and $\$ 8.3$ million $(19.4 \%)$ awarded for applied research. You might think that a lot of the basic research is conducted in horticulture departments because of the new hires in many horticulture departments, but this is not the case. Only $\$ 2.5$ million, or $8 \%$, of the $\$ 34.4$ million for basic grants in the above categories went to horticulture departments. Most is going to plant physiologists in biology departments and many other areas that are not in colleges of agriculture.

The problem is that NRI is being operated too much like the National Science Foundation, which is a basic-science-oriented grant- ing agency. As horticulturists, we should take charge of our own destiny, and demand that some of the NRI reviewers be applied scientists. You cannot tell me that development of the ' 1015 ' sweet onion cultivar, which adds a $\$ 30$ million wholesale value (or $\$ 90$ million retail value) to a state's economy, is not "good science." There is nothing wrong with finding the gene that will dwarf pecan trees, but if it takes 30 years before it can be perfected, we should have some other projects with a quicker pay out or none of our present clientele will be here 30 years from now.

Basic science is important and horticulturists should be active in that area, as they were in developing the 'Flavor Savr' tomato. However, we also have our traditional obligation to serve the horticultural industries because they pay our salaries and are directly within the mission of the land-grant universities. Some of you are not in land-grant universities, but as horticulturists you are practitioners of an applied science that improves the life-styles of people.

\section{Land-grant universities}

Those who have traveled to other countries have found that the research, teaching, and extension programs in the United States are unmatched. Extension education information has been available to small and large growers alike. It has been the investment of the people in the agricultural system that has paid dividends in the form of the nutritious, inexpensive food we currently enjoy. Americans spend only $11 \%$ of their income on food, compared with an average of $25.2 \%$ spent in the rest of the world. Our low-priced food has been the envy of most countries and we should be proud of this system and the part that horticulturists have played in it. Today, less than $2 \%$ of the U.S. population lives on farms. However, horticultural enterprises are not necessarily confined to the farm. There are vast numbers of places in urban settings for horticulturists.

Floriculture and environmental horticulture is the fastest-growing segment in U.S. agriculture in grower cash receipts, averaging 9\% annual growth during 1982-91. In spite of the recessions during the early 1980s and early 1990s, growers' cash receipts continued to grow, reaching $\$ 8.7$ billion in 1991. Floriculture and environmental crops ranked sixth among commodity groups in 1991 in terms of grower cash receipts, behind cattle and calves, dairy products, corn, hogs, and soybeans. However, during the same time, these horticultural operations had the highest average net farm income of any commodity group, at $\$ 53,589$ - four times the average net farm income of all U.S. farms.

People and plants are both natural parts of the larger biological system in the natural world. The discipline of horticulture clearly demands that we regard people and plants as closely linked in every facet of real life. Horticulture, after all, is the science of using plants for the benefit of humankind. This emphasis or awareness of people-plant interaction as a research field leads to sharing between plant 
scientists and social scientists. There is a new level of collaboration between our disciplines and others, such as medicine, psychology, anthropology, history, human ecology, and marketing, that offers exciting future developments. As we enter the new millennium, with its overriding problems of political instability, diminishing resources, and environmental destruction, we will need solutions based in the reality of people living with plants, and we will need to find economically and environmentally stable systems that are politically viable. Horticulturists, with their recognition of the importance of people-plant interactions, can take charge of their own destiny in constructing those solutions.

Horticulturists have a big advantage over other agricultural endeavors that are more confined to rural areas. Horticulturists have a large clientele that is spread throughout all of the socioeconomic groups in urban or rural societies. Horticultural departments that work closely with both urban and rural people will stay alive and well. We must rise up as researchers, teachers, and extension specialists and agents to do a better job than we have ever done before so that the clientele will want more and not stand for a dean or any administrator who wants them to settle for less. I was in a department that was forced into consolidation with agronomy in 1961 by the "merger mania" syndrome that seemed to be sweeping the deans at the time. We had to live with it until pressure from industry and students demanded reinstatement of the department of horticulture in 1975. ASHS was more important to us in those years than ever before, because it gave us name identity and recognition that we had lost on our own campus.

Deans who raise the entrance level to unreasonable heights just to keep up with other colleges are unfair to good solid, highly motivated students from socioeconomically disad- vantaged neighborhoods. I do not think that Abraham Lincoln had this in mind when he signed the act that established land-grant universities because the nation already had Harvard, Yale, and Princeton. The people needed more practical information, and they still do.

I have lived to see an administrator try to run a college of agriculture like a medical school. It did not work, because the agricultural clientele found that too much of the state's resources were being diverted to draw large grants that often did not supply answers to the problems facing their current bottom line.

Administrators should not be afraid to stand up and be counted. Working with clientele will always pay dividends. Take them into advisory committees and pay attention to their advice. If they want more than the funds will allow, ask them to make up the difference. Some of them can be quite persuasive with state legislatures and foundations. We once had an extension director named John Hutchison who was a master at the art of working with people. He never ran from them, but welcomed them with open arms, and the extension programs grew as a result. Hutchison took charge of his own destiny and developed an extremely effective extension program.

\section{Teaching}

Horticulturists have a big advantage over many in other fields because we go into the teaching laboratories, where our students become a part of the creative process. They can see a landscape plan take shape on a computer and then at the site. They can experience learning how to shape a tree through pruning and how to manipulate daylengths to schedule flowers for the holidays. They learn to judge quality by competing in Association of Collegiate Branches judging contests, like the one we had at this annual meeting. Students from northern universities become familiar with okra and pecans, while southern students see cherries and hazel nuts up close and personal.

Develop new courses or give old ones a new twist to interest a wider variety of students. I have been teaching a tropical horticultural crops course for some time, taken primarily by students from the College of Agriculture and Life Science. The university is adding an international course requirement to their core curriculum, and has expressed interest in what I consider a good, solid horticulture course that will be taken by liberal arts students.

Do something different and exciting. Take a class of 20 students to Central America so they will have something to do during spring break. They can earn a 1-hour credit and experience a different culture and a completely different set of horticultural crops. We did this last spring and, among other things, toured the immaculate, highly efficient Goldsmith Flower Seed production facility at the foot of a volcano near Guatemala City. They germinate seed with geothermal energy in an ideal climate for flower production. This large facility employs 1000 people and is enclosed in screenhouses to prevent insect pollination. Hand-emasculation and hand-pollination leads to a beautiful potpourri of flower colors and shapes. They are all marked as selfs, or hybrids, $F_{1}$, or $F_{2}$ generations. The segregation was thus laid out as if one were walking through the pages of a text book on Mendelian inheritance.

The students were excited about seeing such a spectacle, and many commented that they were sure that their professors had never seen anything like that. It was exciting, and I can recommend it to you. Your students will appreciate you because they have been shown how to take charge of their own destiny. 